\title{
Anatomy of Consolida orientalis (Gay) Schröd. (Ranunculaceae): Root, stem and leaf
}

\author{
Safa Gümüșok (1), Muhammed Mesud Hürkul' (i) \\ ${ }^{1}$ Ankara University, Faculty of Pharmacy, Department of Pharmaceutical Botany, Ankara, Turkey
}

ORCID IDs of the authors: S.G. 0000-0002-7068-444X; M.M.H. 0000-0002-9241-2496

Cite this article as: Gumusok, S., \& Hurkul, M. M. (2021). Anatomy of Consolida orientalis (Gay) Schröd. (Ranunculaceae): Root, stem and leaf. İstanbul Journal of Pharmacy, 51(3), 398-402.

\begin{abstract}
Background and Aims: Consolida orientalis (J.Gay.) Schrödinger belonging to the Ranunculaceae family, which is called "morçiçek" in Turkey. It can be recognized by its laciniae linear leaves, intense violet flower, and follicle fruit. The aim of the present study is to elucidate the anatomical properties of $C$. orientalis, as one of the medically important plant species of Ranunculaceae family.

Methods: Plant material was collected from Kahramankazan (Ankara-Turkey). The samples were protected in $70 \%$ alcohol. The transverse and surface sections were investigated by light microscope and photographed.

Results: The root is characterized by a periderm, pericyclic sclerenchymatous ring, and vessels embedded in sclerenchymatous pith cells. It was observed that in the anatomical features of the stem, the adaxial walls of epidermis cells curved outward and were covered with a thick cuticle layer. Moreover, stomata were observed in the epidermis and the stem had hairs only at the above parts, while other parts were bare. These hairs consisted of both glandular (with a long stalk) and non-glandular (unicellular, silicified) types. The leaf is broadly v-shaped, monofacial and has a 1-layer epidermis. Ranunculaceous stomata and non-glandular (unicellular, silicified and slightly bowed) hairs were observed on both surfaces.

Conclusion: The root, stem, and leaf anatomy of $C$. orientalis was studied for the first time. The anatomical features described in detail with reference reports could be helpful in future taxonomic studies.
\end{abstract}

Keywords: Ranunculaceae, Consolida orientalis, plant anatomy, Turkey

\section{INTRODUCTION}

Ranunculaceae is a widely propagated and prolific family, spreading across all continents except Antarctica and includes 52 accepted genera (Heywood, Brummitt, \& Culham, 2007; POWO, 2021). The family usually consists of perennial herbs, and rare woody climbers. The flowers are actinomorphic or zygomorphic. Achenes, follicles or baccate are fruit types of the family (Brummitt, 1992; Davis, 1965; Evans, 2002).

The most common chemical substances in this family are alkaloids, flavonoids, phenolic acids, phytosterols, fatty acids, and essential oils and also includes important medicinal plants with insecticidal, antiparasitic, antimicrobial, antiviral, antitumor, and antioxidant properties (Evans, 2002; Hao, 2018; Yin, Cai \& Ding, 2020).

Consolida (DC.) S.F. Gray members are annual herbs, spread from the West Mediterranean to Central Asia, and Anatolia is accepted as the diversity centre of the Consolida genus (Davis, 1965). Consolida orientalis (Gay) Schröd. can be recognized by its laciniae linear leaves, intense violet flower, and follicle fruit (Davis, 1965). According to current reports, the plant named Delphinium ajacis

Address for Correspondence:

Muhammed Mesud HÜRKUL, e-mail: huerkulmm@gmail.com

This work is licensed under a Creative Commons Attribution 4.0 International License.
Submitted: 16.02 .2021

Revision Requested: 04.06.2021

Last Revision Received: 06.06.2021

Accepted: 24.06 .2021

Published Online: 06.12.2021 
L. and C. orientalis are synonymous (IPNI, 2021; POWO, 2021). According to Güner, Aslan, Ekim, Vural \& Babaç, (2012), C. orientalis is named "morçiçek" in Turkey, and its synonyms are the Delphinium orientale Gay, D. bithynicum Griseb., D. hispanicum Willk., D. orientale subsp. hispanicum (Willk.) Batt., D. orientale var. brevicalcaratum Huth, D. ajacis var. orientale (Gay) Finet \& Gagnep.

The Consolida and Delphinium species are morphologically mixed with each other (Yin et al., 2020). Researching the anatomical features and differences of plant organs is of great importance in distinguishing taxonomically mixed species. There have been no comprehensive anatomical studies done on the Consolida species until now. With other taxonomic features, the anatomical knowledge is required for Consolida taxa. The anatomical studies evaluated until now consisted of generalizations on the Ranunculaceae family by revealing the anatomical features of certain taxa (Maxwell, 1893; Metcalfe \& Chalk, 1965). In this study, the anatomical features of C. orientalis root, stem, and leaf were examined in detail.

\section{MATERIALS AND METHODS}

The plant material was collected from Kahramankazan (Ankara/Turkey) and described by Safa Gümüşok. A voucher specimen was deposited in the Ankara University Faculty of Pharmacy Herbarium (AEF 29964) in Turkey. The samples for anatomical studies were protected in $70 \%$ alcohol. The transverse and surface sections were cut by hand with a razor blade into microscopic preparation form. The Sartur solution (Türk Farmakopesi, 2017) was used in microscopic examinations. A Leica DM 4000B microscope was used for anatomical analysis and micro photographing.

\section{RESULTS AND DISCUSSION}

\section{Root anatomy}

The transverse section of the root consists of the periderm, pericyclic derivatives, and vascular tissues. The root consists of phellem layers outward and 1-2 layered phellogen and multi layered phelloderm inward. The phellem is composed of 1-5 layers of cells having an isodiametric or elongated shape. Cortex parenchyma cells are almost absent. Sometimes, under the pit walled single-row endodermis, there is a pericycle forming a sclerenchyma cap. The vessels of the root are embedded in lignified cells. A sclerenchymatous cap are present immediately on the outside of the phloem. Polyarch xylem is branched into 10-12 radial multiples (Figure 1).

\section{Stem anatomy}

The epidermis is covered with a very thick cuticle layer in the transverse section of the stem. Its cells are single-layered, rounded, the adaxial and abaxial wall is thick, side walls are thin, the adaxial walls are curved outward, and the intracellular space is large. Stomata is observed. The cortex parenchyma cells, except cells in the oval shaped last layer, are longitudinally elongated, thin-walled, dense starchy, and consist of 2-4 rows of cells. Collateral type vascular bundles are arranged in a circle. The xylem are indistinctly concave where adjoining the phloem. Phloem are bounded externally by the pericyclic

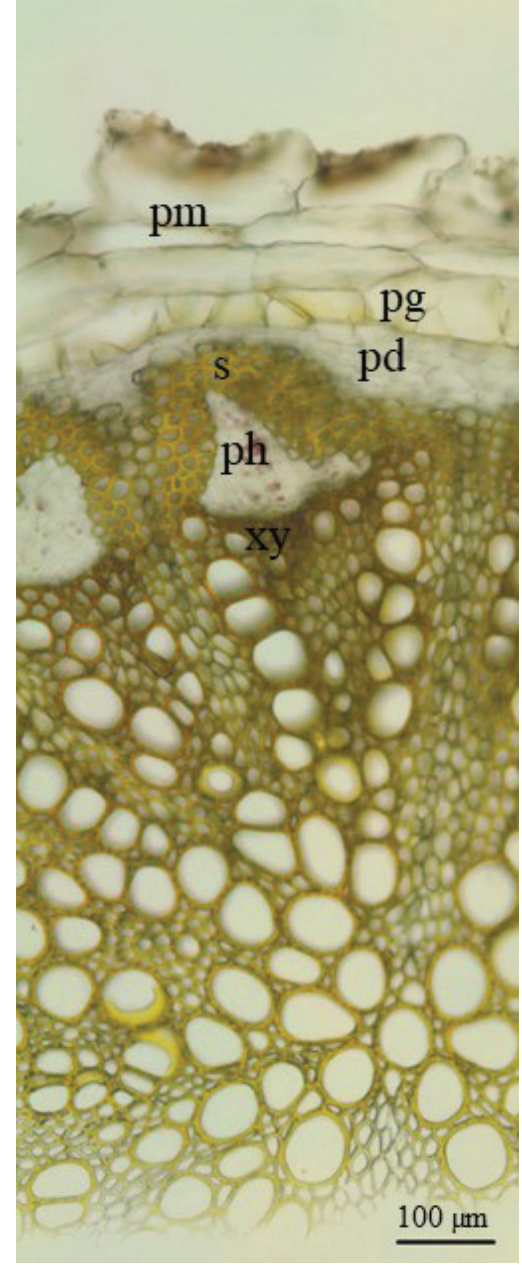

Figure 1. Transverse section of root in C. orientalis. pd: phelloderm, pg: phellogen, ph: phloem, pm: phellem, s: sclerenchyma, xy: xylem

sclerenchymatous cap. The rays as 10-12 arms extend between vascular bundles, consist of 2-5 rows of cells laterally and contain very dense starch. Pith cells are thick-walled, sometimes with pitted walls, rounded, dense starchy, lignified cells, and intracellular spaces are large (Figure 2a, b, c, d). The above parts of the stem differ from the other parts in terms of hairs. The above parts of the stem covered by densely glandular (with a long stalk) and non-glandular (unicellular, silicified) types hairs, and other parts are bare (Figure 3a, b).

\section{Leaf anatomy}

The transverse section of leaf was observed as being broadly vshaped and monofacial. The epidermis is composed of singlelayer cells surrounded by a very thin cuticle layer. The shape of cells is ovoid and the outer walls are thick. The upper epidermis cells are larger than lower epidermis cells. There are nonglandular hairs (unicellular, silicified) and stomata on both the upper and lower epidermis. The mesophyll consists of tightly arranged parenchymatous cells. The palisade parenchyma consists of single-layer, long-cylindrical, thin-walled cells. The cells of the spongy parenchyma between the palisade layers are isodiametric, thin-walled, 2-6 rows and fills between the vascular bundles. Both palisade and spongy parenchyma cells 

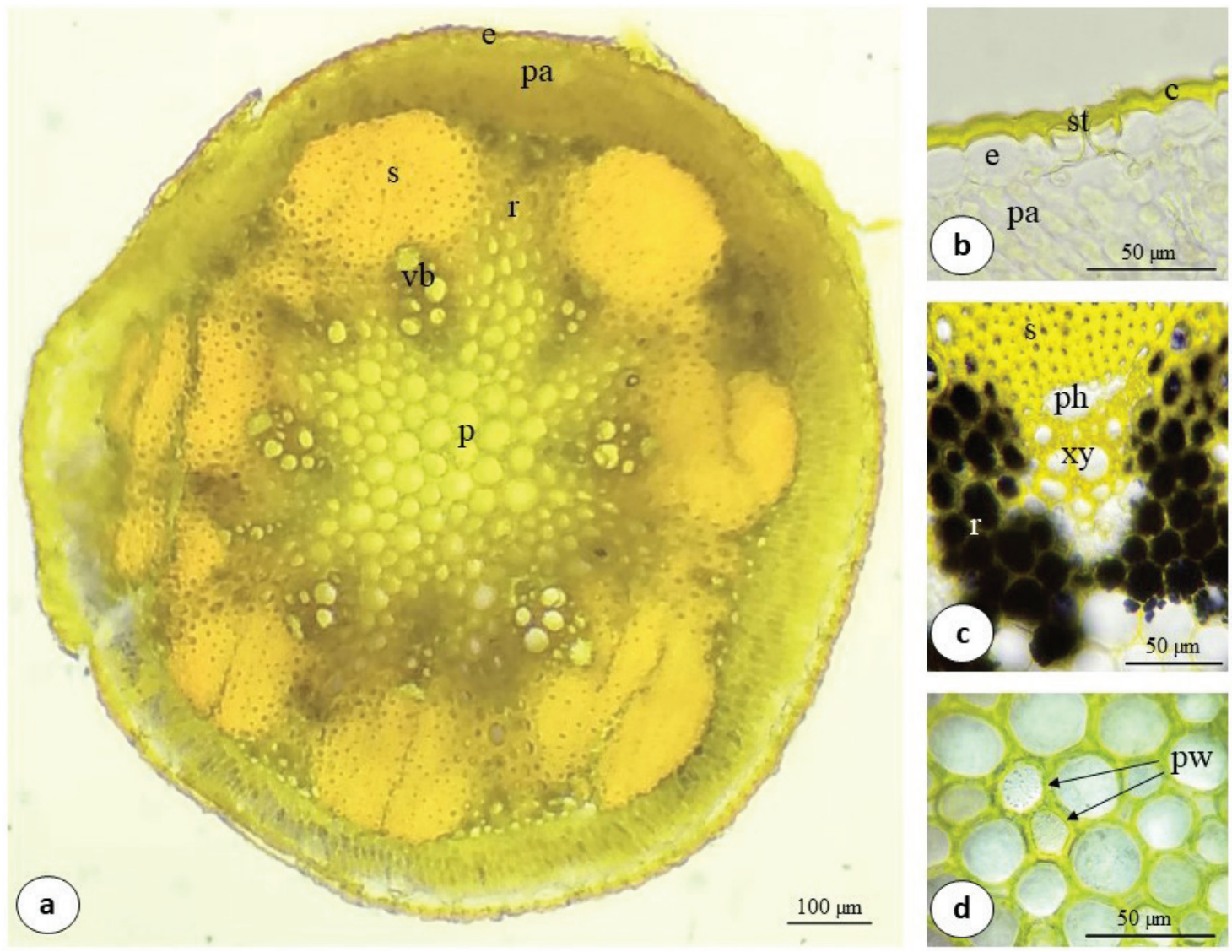

Figure 2. Transverse section of stem in C. orientalis.

c: cuticle, e: epidermis, p: pith, pa: cortex parenchyma, ph: phloem, pw: pitted walls of pith cells, r: ray, s: sclerenchyma, st: stomata, vb: vascular bundle, $x y$ : xylem
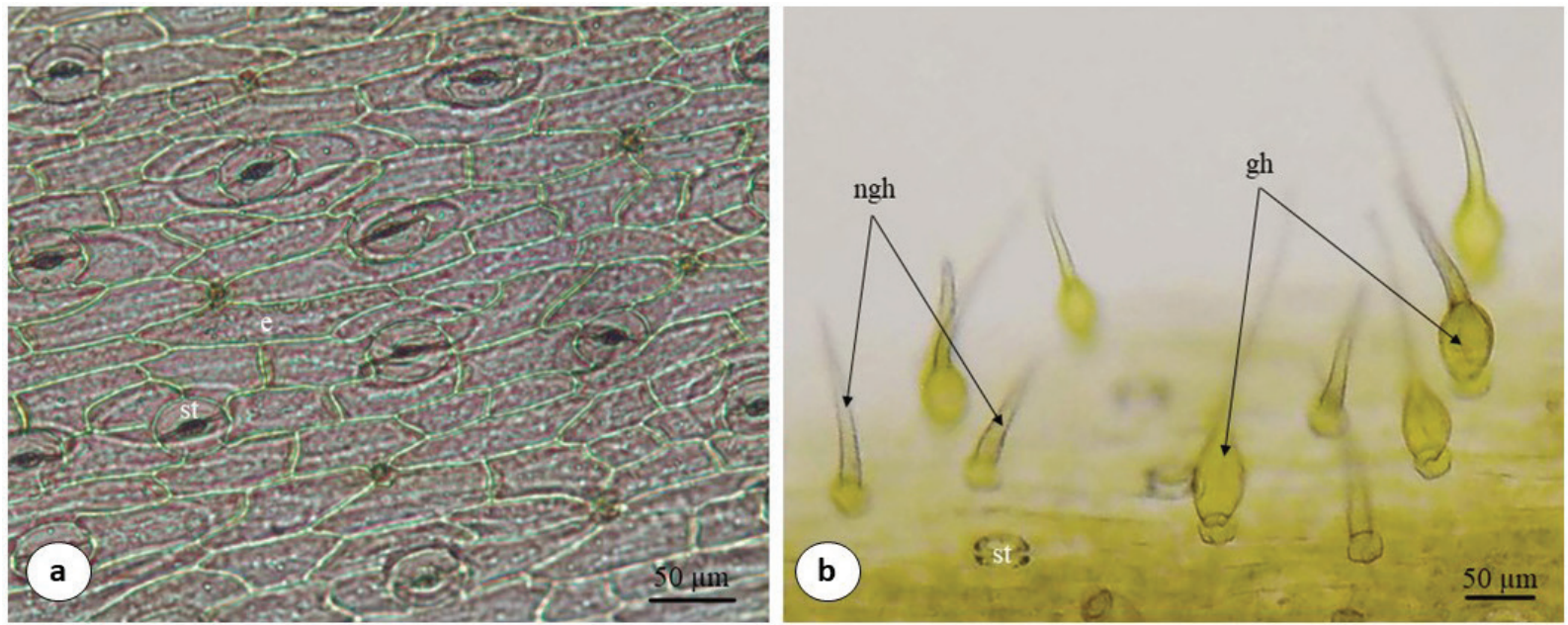

Figure 3. Surface sections of stem in C. orientalis.

e: epidermis, gh: glandular hair, ngh: non-glandular hair, st: stomata

contain abundant starch. The vascular bundles are surrounded by a compactly arranged bundle sheath (Figure 4a, b, c, d).

Both epidermal structures of the leaf were observed as similar in surface sections. The cells of epidermis with sinuous anticlinal walls contains ranunculaceous stomata and non- glandular hairs. The hairs are unicellular, silicified and slightly bowed (Figure 5a, b, c, d).

According to Metcalfe \& Chalk (1965); the root of Ranunculaceae has a sclerenchymatous pith region in anatomical structure, a sclerenchymatous cap located on the adaxial side of vascular 

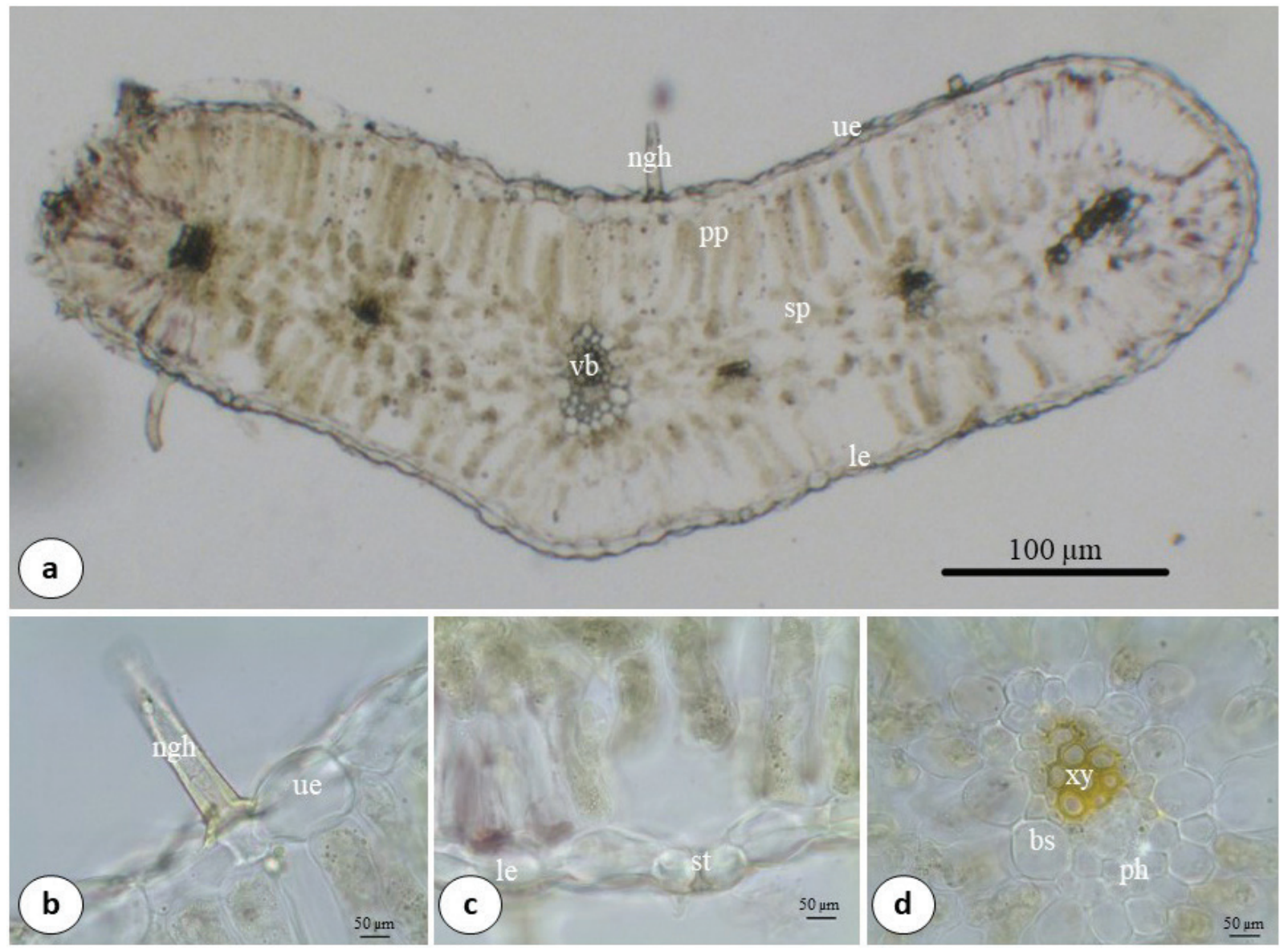

Figure 4. Transverse section of leaf in C. orientalis.

bs: bundle sheath, le: lower epidermis, ngh: non-glandular hair, pp: palisade parenchyma, ph: phloem, sp: spongy parenchyma, st: stomata, ue: upper epidermis, vb: vascular bundle, $x y$ : xylem
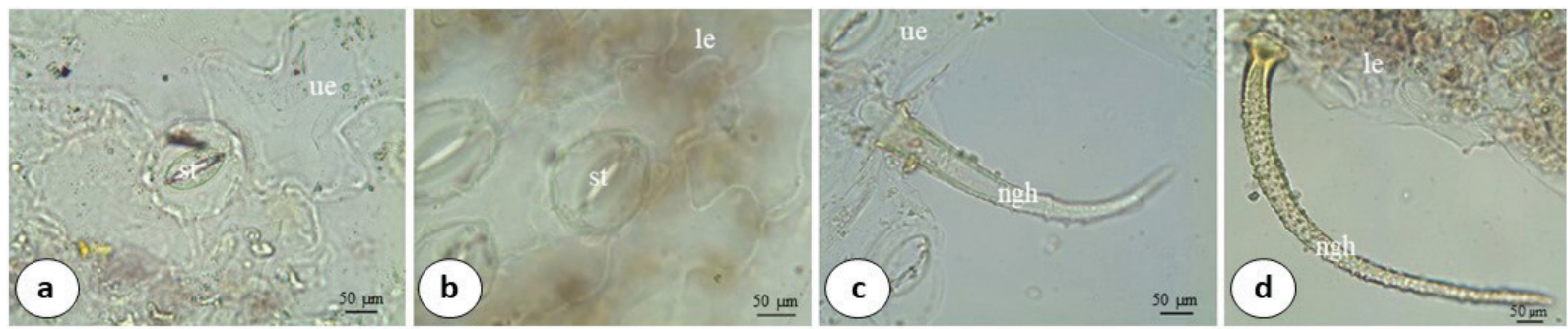

Figure 5. Surface sections of leaf in C. orientalis.

le: lower epidermis, ngh: non-glandular hair, st: stomata, ue: upper epidermis

bundles. The C. orientalis root, as characterized by the periderm layer, pericyclic sclerenchymatous cap and vessels embedded in the sclerenchymatous pith according to the results, is branched into 10-12 radial multiples polyarch xylem. Generally the Ranunculaceae family root is known as tetrarch (Maxwell, 1893; Yentür, 1995). However, the number of xylem arms also correlates with the viability and size of the root (Yentür, 1995). Periderm layers can be clearly distinguished from each other, as phellem, phellogen, and phelloderm. Additionally, cortex parenchyma cells are absent in anatomical features of the $C$. orientalis root.
The results show that the stem of $C$. orientalis is characterized by a monolayer epidermis with stomata and thick cuticle layer. The epidermis layer has glandular and non-glandular hairs, but only on above parts of the stem, other parts are bare. The cortex parenchyma and sclerenchymatous clusters are in a regular ring form. Vascular bundles in the stem are a collateral type, adaxial side of phloem enclosed by a sclerenchymatous cap. The concave xylem is found in abaxial side of the phloem. Lignified pith cells have large intercellular space and sometimes pitted walls were observed. According to Metcalfe \& Chalk (1965), the stem of the Ranunculaceae family has a collateral-type vascular bundle with concave xylem and pericyclic sclerenchyma 
ring, with additional non-glandular hairs on the stem. Pith cells are also lignified. What makes this report different is that glandular hairs were observed on above parts of the stem.

According to Metcalfe \& Chalk (1965), the Ranunculaceae family has the characteristics of a monofacial or centric leaf. The epidermis has ranunculaceous stomata with glandular and non-glandular hairs. In addition, the lower epidermal cell anticlinal walls are sinuous. Except for the presence of glandular hair, the data of Metcalfe \& Chalk (1965) agrees with the findings in this report. In addition, the report results showed that the upper epidermis of monofacial leaf was also sinuous. The non-glandular hairs of the leaf are unicellular, silicified and slightly bowed.

In conclusion, the root, stem and leaf anatomy of C. orientalis was studied for the first time. The anatomical features described in detail with reference reports could be helpful in future taxonomic studies.

Peer-review: Externally peer-reviewed.

Author Contributions: Conception/Design of Study- S.G., M.M.H.; Data Acquisition- S.G., M.M.H.; Data Analysis/Interpretation- M.M.H.; Drafting Manuscript- S.G., M.M.H.; Critical Revision of Manuscript- S.G., M.M.H.; Final Approval and Accountability- S.G., M.M.H.

Conflict of Interest: The authors have no conflict of interest to declare.

Financial Disclosure: Authors declared no financial support.

\section{REFERENCES}

- Brummitt, R. K. (1992). Vascular plant families and genera. Richmond, UK: Royal Botanic Gardens, Kew.

- Davis, P. H. (1965). Flora of Turkey and the East Aegean Islands, (Vol. 1, pp.119-134). Edinburgh, UK: Edinburgh University Press.

- Evans, W. C. (2002). Trease and evans pharmacognosy. Philadelphia, USA: Saunders.

- Güner, A., Aslan, S., Ekim, T., Vural, M., \& Babaç, M. T. (2012). Türkiye bitkileri listesi (Damarlı bitkiler) [Turkey plant list (Vascular plants)]. Istanbul, Türkiye: Nezahat Gökyigit Botanik Bahçesi Yayınları.

- Hao, D. C. (2018). Ranunculales medicinal plants: Biodiversity, chemodiversity and pharmacotherapy. London, UK: Academic Press.

- Heywood, V. H., Brummitt, R. K., Culham, A., \& Seberg, O. (2007). Flowering plant families of the world. Ontario, Canada: Firefly Books.

IPNI. (2021, January 05). International Plant Names Index. Retrieved from https://www.ipni.org/n/1000018-1

- Maxwell, F. B. (1893). A comparative study of the roots of Ranunculaceae. Botanical Gazette, 18(1), 8-16.

- Metcalfe, C. R., \& Chalk, L. (1965). Anatomy of dicotyledones. (Vol. 2). Oxford, UK: Clarendon Press.

- POWO. (2021, January 05). Plants of the World Online. Retrieved from http://www.plantsoftheworldonline.org/taxon/urn:Isid:ipni. org:names:30000277-2

- Türk Farmakopesi (2017). Türk Farmakopesi, genel monograflar I [Turkish Pharmacopoeia, general monographs I]. Ankara, Türkiye: T.C. Sağlık Bakanlığı.

- Yentür, S. (1995). Bitki anatomisi [Plant anatomy]. Istanbul, Türkiye: İstanbul Üniversitesi Yayınları.

- Yin, T., Cai, L., \& Ding, Z. (2020). A systematic review on the chemical constituents of the genus Consolida (Ranunculaceae) and their biological activities. RSC Advances, 10(58), 35072-35089. 